\title{
Midodrine Treatment of Orthostatic Hypotension in Patients with Acute Tetraplegia
} Akut Tetraplejili Hastalarda Ortostatik Hipotansiyonda Midodrin Tedavisi

\author{
Ümüt GÜZELKÜÇÜK, Iltekin DUMAN, Bilge YILMAZ, Arif Kenan TAN \\ Gülhane Military Medical Academy Department of Physical Medicine and Rehabilitation Turkish Armed Forces Rehabilitation Center, Ankara, Turkey
}

\section{Intruduction}

Orthostatic hypotension $(\mathrm{OH})$ is one of the complications in patients with spinal cord injury ( $\mathrm{SCl}$ ) particularly in the acute stage. Impairment in the autonomic nervous system, usually in patients with cervical and high thoracic $\mathrm{SCl}$, causes $\mathrm{OH}$ that is defined as decrease in systolic blood pressure of at least $20 \mathrm{~mm} \mathrm{Hg}$ or diastolic blood pressure of at least $10 \mathrm{~mm} \mathrm{Hg}$ upon changing body position from supine to upright posture. It results from an inefficient response to postural changes in blood pressure. $\mathrm{OH}$ may be symptomatic or asymptomatic. Symptoms of $\mathrm{OH}$ include dizziness, light-headedness, fainting, blurred vision, muscle weakness, fatigue, nausea, palpitations, and headache (1-4).

Non-pharmacological interventions that have been used are salt and fluid regulation, pressure to the abdominal region, upper body exercise, functional electrical stimulation (FES) applied to the legs, compression bandages and/or pressure stockings and tilt training program $(3,5)$. Pharmacological treatment includes agents acting on blood vessels, on blood volume or on other pressor mechanisms. The medications used are fludrocortisone, pyridostigmine, ergotamine, ephedrine, desmopressin, erythropoietin and midodrine $(3,4,6)$.

We experienced two cases of tetraplegia having $\mathrm{OH}$ treated with midodrine that did not respond to conventional nonpharmacological interventions. Both of the patients were women. One of them was 33-year-old with C4 tetraplegia AIS-A and the other was 19-year-old with C5 tetraplegia AIS-A. The subjects were in acute stage of $\mathrm{SCl}$ that were in the first 3 months postinjury. They continued to have $\mathrm{OH}$ during transfer to wheelchair or tilt table exercises despite use of antiembolic compression bandage, abdominal binder, and progressive exercises with tilt table. Five $\mathrm{mg} / \mathrm{d}$ midodrine in two divided doses was started. Improvement in symptoms was observed in both of the patients after 20 days, thus, the dosage was decreased to $2.5 \mathrm{mg} / \mathrm{d}$ in two divided doses. One month later, patients' tolerated tilt angle was 90 degrees, so midodrine was stopped in both of the patients. Midodrine was not continued in one of the patients. In the other patient, midodrine $2.5 \mathrm{mg} / \mathrm{d}$ was started again one week later because $\mathrm{OH}$ continued occasionally. Autonomic dysreflexia (AD) was not observed. No side effects were observed.

The predisposition to $\mathrm{OH}$ following $\mathrm{SCl}$ is not fully understood, but it is thought to be multifactorial (3). Following $\mathrm{SCl}$, the low level of efferent sympathetic activity and the loss of reflex vasoconstriction are among the major causes of $\mathrm{OH}$. $\mathrm{OH}$ is more common in tetraplegia than in paraplegia. $\mathrm{OH}$ persisting during the first month following SCl was reported to occur in $74 \%$ of cervical and in $20 \%$ of upper thoracic motor complete SCl patients (7). Both of our two patients had complete tetraplegia. We obtained supine hypotension and $\mathrm{OH}$ in our patients within the first three months after injury.

Non-pharmacologic measures should be the first choice of treatment in $\mathrm{OH}$. In both of our two patients, we started midodrine because despite conventional non-pharmacological interventions and physical therapy, supine hypotension and $\mathrm{HO}$ did not resolve and progression in tilt training was slow.

Address for Correspondence/Yazışma Adresi: Ümüt Güzelküçük MD, Gülhane Military Medical Academy Department of Physical Medicine and Rehabilitation Turkish Armed Forces Rehabilitation Center, Ankara, Turkey Phone: +90 3122911603 E-mail: druguzelkucuk@yahoo.com 
Midodrine, the prodrug of desglymidodrine, is a peripheral, selective alpha-1 adrenergic receptor agonist that increases blood pressure via arterial and venous vasoconstriction. Usual doses of midodrine ranges from 2.5 to $10 \mathrm{mg}$ two or three times a day $(4,8,9)$. We used $5 \mathrm{mg} / \mathrm{d}$ and decreased to $2.5 \mathrm{mg} / \mathrm{d}$ in our patients. With the use of midodrine, their supine blood pressures and tolerated tilt angles increased in one week and symptomatic $\mathrm{OH}$ resolved in one month. $\mathrm{OH}$ recurred in one of the patients after one week of drug cessation, thus, midodrine started again.

Since midodrine does not cross the blood-brain barrier, it is presumed to have no central nervous system effects (9). The most commonly reported side effects include piloerection, pruritus, mydriasis, palpitations, tachycardia, headaches, urinary retention and supine hypertension $(4,8)$. None of the side effects was observed in our patients. We suggest that, in patients with higher level $\mathrm{SCl}, \mathrm{AD}$ might be another adverse event with the use of midodrine since such patients are prone to develop $A D$. We did not observe $A D$ in our patients.

In our opinion, among these side effects, urinary retention is especially important in patients with $\mathrm{SCl}$ who void voluntarily. Because of its alpha- 1 adrenergic effects, midodrine causes an increase in the tone of the vesical sphincter, which may potentially lead to progressive retention of urine, particularly in patients with $\mathrm{SCl}$ who void urine spontaneously. Furthermore, midodrine may aggravate detrusorsphincter dyssynergia, which can lead to hydroureteronephrosis (10). We suggest if a patient continues to require midodrine to control postural hypotension, intermittent catheterization combined with anticholinergic therapy should be recommended instead of spontaneous voiding.

$\mathrm{OH}$ is an important clinical problem for patients with $\mathrm{SCl}$ since it interferes with ability to perform exercises and activities of daily living (11). It is impossible to take steps without solving the $\mathrm{OH}$ problem in the rehabilitation of $\mathrm{SCl}$. Thus, $\mathrm{OH}$ delays the rehabilitation of patients with $\mathrm{SCl}$, especially in acute stage. $\mathrm{OH}$ prevented to get the targets and delayed rehabilitation in both of our patients which caused their longer stay at hospital.
We suggest that the use of midodrine might be considered in patients with $\mathrm{SCl}$ whose orthostatic symptoms are refractory to conventional non-pharmacological interventions. We obtained beneficial effects regarding symptoms and rehabilitation with no significant side effects. Urinary adverse effects, supine hypertension and $\mathrm{AD}$ should be followed closely in $\mathrm{SCl}$ patients using midodrine.

\section{References}

1. Shibao C, Okamoto L, Biaggioni I. Pharmacotherapy of autonomic failure. Pharmacol Ther 2012;134:279-86.

2. Popa C, Popa F, Grigorean VT, Onose G, Sandu AM, Popescu M, et al. Vascular dysfunctions following spinal cord injury. J Med Life 2010;3:275-85.

3. Dinçer Ü. Medulla spinalis yaralanmasında otonomik disfonksiyonlar ve tedavisi eğitim. Türk Fiz Tıp Rehab Derg 2010;56(Özel Sayı2):93-8.

4. Krassioukov A, Eng J], Warburton DE, Teasell R, Spinal cord injury rehabilitation evidence research team. A systematic review of the management of orthostatic hypotension after spinal cord injury. Arch Phys Med Rehabil 2009;90:876-85.

5. Gillis DJ, Wouda M, Hjeltnes N. Non-pharmacological management of orthostatic hypotension after spinal cord injury: a critical review of the literature. Spinal Cord 2008;46:652-9.

6. Lanier JB, Mote MB, Clay EC. Evaluation and management of orthostatic hypotension. Am Fam Physician 2011;84:527-36.

7. Sidorov EV, Townson AF, Dvorak MF, Kwon BK, Steeves I, Krassioukov A. Orthostatic hypotension in the first month following acute spinal cord injury. Spinal Cord 2008;46:65-9.

8. Jabary NS, Sarabia R, Sanchez T, Gordillo R. Midodrine treatment in the management of severe orthostatic hypotension after hemangioblastoma surgery. Acta Neurochir (Wien) 2007;149:303-5.

9. Fujisaki $K$, Kanai $H$, Hirakata $H$, Nakamura $S$, Koga $Y$, Hattori $F$, et al. Midodrine hydrochloride and L-threo-3,4-dihydroxy-phenylserine preserve cerebral blood flow in hemodialysis patients with orthostatic hypotension. Ther Apher Dial 2007;11:49-55.

10. Vaidyanathan S, Soni BM, Hughes PL. Midodrine: insidious development of urologic adverse effects in patients with spinal cord injury: a report of 2 cases. Adv Ther 2007;24:712-20.

11. Nieshoff EC, Birk TJ, Birk CA, Hinderer SR, Yavuzer G. Double-blinded, placebo-controlled trial of midodrine for exercise performance enhancement in tetraplegia: a pilot study. J Spinal Cord Med 2004;27:219-25. 